University of Vermont

UVM ScholarWorks

Rubenstein School of Environment and Natural Rubenstein School of Environment and Natural Resources Faculty Publications

Resources

8-30-2013

\title{
Beyond climate-smart agriculture: Toward safe operating spaces for global food systems
}

\author{
Henry Neufeldt \\ World Agroforestry Centre \\ Molly Jahn \\ University of Wisconsin-Madison \\ Bruce M. Campbell \\ CGIAR Research Program on Climate Change \\ John R. Beddington \\ Government Office for Science \\ Fabrice DeClerck \\ Bioversity International
}

See next page for additional authors

Follow this and additional works at: https://scholarworks.uvm.edu/rsfac

Part of the Agriculture Commons, Climate Commons, Community Health Commons, Human Ecology

Commons, Nature and Society Relations Commons, Place and Environment Commons, and the

Sustainability Commons

\section{Recommended Citation}

Neufeldt H, Jahn M, Campbell BM, Beddington JR, DeClerck F, De Pinto A, Gulledge J, Hellin J, Herrero M, Jarvis A, LeZaks D. Beyond climate-smart agriculture: toward safe operating spaces for global food systems. Agriculture \& Food Security. 2013 Dec;2(1):1-6.

This Article is brought to you for free and open access by the Rubenstein School of Environment and Natural Resources at UVM ScholarWorks. It has been accepted for inclusion in Rubenstein School of Environment and Natural Resources Faculty Publications by an authorized administrator of UVM ScholarWorks. For more information, please contact scholarworks@uvm.edu. 


\section{Authors}

Henry Neufeldt, Molly Jahn, Bruce M. Campbell, John R. Beddington, Fabrice DeClerck, Alessandro De Pinto, Jay Gulledge, Jonathan Hellin, Mario Herrero, Andy Jarvis, David LeZaks, Holger Meinke, Todd

Rosenstock, Mary Scholes, Robert Scholes, Sonja Vermeulen, Eva Wollenberg, and Robert Zougmoré 


\title{
Beyond climate-smart agriculture: toward safe operating spaces for global food systems
}

\author{
Henry Neufeldt ${ }^{1 *}$, Molly Jahn ${ }^{2 \dagger}$, Bruce M Campbell ${ }^{3,4}$, John R Beddington ${ }^{5}$, Fabrice DeClerck ${ }^{6}$, \\ Alessandro De Pinto ${ }^{7}$, Jay Gulledge ${ }^{8}$, Jonathan Hellin ${ }^{9}$, Mario Herrero ${ }^{10}$, Andy Jarvis ${ }^{3,4}$, David LeZaks ${ }^{2}$, \\ Holger Meinke ${ }^{11,12}$, Todd Rosenstock ${ }^{1}$, Mary Scholes ${ }^{13}$, Robert Scholes ${ }^{14}$, Sonja Vermeulen ${ }^{3,15}$, Eva Wollenberg ${ }^{3,16}$ \\ and Robert Zougmoré $e^{3,17}$
}

\begin{abstract}
Agriculture is considered to be "climate-smart" when it contributes to increasing food security, adaptation and mitigation in a sustainable way. This new concept now dominates current discussions in agricultural development because of its capacity to unite the agendas of the agriculture, development and climate change communities under one brand. In this opinion piece authored by scientists from a variety of international agricultural and climate research communities, we argue that the concept needs to be evaluated critically because the relationship between the three dimensions is poorly understood, such that practically any improved agricultural practice can be considered climate-smart. This lack of clarity may have contributed to the broad appeal of the concept. From the understanding that we must hold ourselves accountable to demonstrably better meet human needs in the short and long term within foreseeable local and planetary limits, we develop a conceptualization of climate-smart agriculture as agriculture that can be shown to bring us closer to safe operating spaces for agricultural and food systems across spatial and temporal scales. Improvements in the management of agricultural systems that bring us significantly closer to safe operating spaces will require transformations in governance and use of our natural resources, underpinned by enabling political, social and economic conditions beyond incremental changes. Establishing scientifically credible indicators and metrics of long-term safe operating spaces in the context of a changing climate and growing social-ecological challenges is critical to creating the societal demand and political will required to motivate deep transformations. Answering questions on how the needed transformational change can be achieved will require actively setting and testing hypotheses to refine and characterize our concepts of safer spaces for social-ecological systems across scales. This effort will demand prioritizing key areas of innovation, such as (1) improved adaptive management and governance of social-ecological systems;

(2) development of meaningful and relevant integrated indicators of social-ecological systems; (3) gathering of quality integrated data, information, knowledge and analytical tools for improved models and scenarios in time frames and at scales relevant for decision-making; and (4) establishment of legitimate and empowered science policy dialogues on local to international scales to facilitate decision making informed by metrics and indicators of safe operating spaces.
\end{abstract}

Keywords: Adaptation, Climate-smart agriculture, Development, Food security, Mitigation, Safe space for humanity

\section{Introduction: history of the concept of climate-smart agriculture}

If trends in human diet and waste in food systems remain unchecked, food production would have to increase by about $70 \%$ to feed an estimated 9 billion people by 2050 , with unprecedented consequences for the environment

\footnotetext{
*Correspondence: h.neufeldt@cgiar.org

${ }^{\dagger}$ Equal contributors

'World Agroforestry Centre (ICRAF), Nairobi, Kenya

Full list of author information is available at the end of the article
}

and society. The food price spikes of recent years have reinforced awareness of obvious links between political and economic stability and food security. As a consequence, agricultural development is now the focus of renewed attention in both the research and policy communities. In describing tensions between maximizing global agricultural productivity, increasing resilience of agricultural systems in the face of climate change and mitigating greenhouse gas (GHG) emissions from agriculture, the term climate-smart agricultural development was first used in 2009 [1,2]. A

\section{Biomed Central}


year later, at the First Global Conference on Agriculture, Food Security and Climate Change at the Hague, the concept of climate-smart agriculture (CSA) was presented and defined as agriculture that "sustainably increases productivity, enhances resilience, reduces/removes greenhouse gas emissions, and enhances achievement of national food security and development goals" [3]. This definition represented an attempt to set a global agenda for investments in agricultural research and innovation, joining the agriculture, development and climate change communities under a common brand.

Drawing on this original framing, CSA has been applied to diverse aspects of agriculture, ranging from field-scale agricultural practices to food supply chains and food systems generally. Beyond agricultural practices and outcomes, a wide array of institutions, policies, finance, safety nets, capacity-building and assessment have all been identified as enabling CSA. Following the Second Global Conference on Agriculture, Food Security and Climate Change in Hanoi in 2012, the recently published Climate-Smart Agriculture Sourcebook further advanced the concept with the intention of benefiting primarily smallholder farmers and vulnerable people in developing countries [4].

Building on this brief outline of the concept, in this article we first lay out major implications and shortcomings of what CSA means in practice. We then describe the challenges we are facing in assessing our trajectories toward long-term safe operating spaces of social-ecological systems for humanity within planetary and local boundaries and suggest an agenda for immediate action required to step up to meet the challenges.

\section{Climate-smart agriculture encompasses virtually any agricultural practice}

Although in principle only agricultural practices that encompass all components of CSA should be branded as "climate-smart," the term has been used very liberally because it is unclear how the different dimensions interact. Therefore, virtually any agricultural practice that improves productivity or the efficient use of scarce resources can be considered climate-smart because of the potential benefits with regard to food security, even if no direct measures are taken to counter detrimental climate effects. In addition, virtually any agricultural practice that reduces exposure, sensitivity or vulnerability to climate variability or change (for example, water harvesting, terracing, mulching, drought-tolerant crops, index insurances, communal actions) are also climate-smart because they enhance farmers' ability to cope with weather extremes. Likewise, agricultural practices that sequester carbon from the atmosphere (for example, agroforestry, minimum tillage), reduce agricultural emissions (for example, manure management, biogas plants, reduced conversion of forests and rangeland) or improve resource use efficiency (for example, higher productivity crop and livestock breeds, improved crop management and animal husbandry) can all be considered climate-smart because they contribute to slowing the rate of climate change. CSA has been a powerful concept to direct a focus on the climate change-agriculture nexus and has united the agriculture, climate change and development communities under one brand. Almost any agricultural practice or outcome currently qualifies as climate-smart, however, suggesting that CSA is a triplewin for all without regrets, losers and trade-offs. Thus, CSA can easily be appropriated for a wide range of even conflicting agendas.

\section{What climate-smart agriculture fails to encompass}

By recognizing links between our choices in agricultural systems and outcomes related to food systems in human dimensions, the incorporation of food security as an imperative for CSA differentiates it from concepts such as sustainable intensification [5] and ecoefficiency [6]. Balancing priorities at the intersections of food security, adaptation and mitigation, however, always occurs in the context of region-specific conditions and cultures. Why should resource-poor farmers invest in agricultural practices that may reduce emissions if there are few if any immediate benefits related to food or water security? ("It's hard to be green when you are in the red.") CSA, as currently conceived and implemented, fails entirely to recognize different actors, incentives and interactions between different (but related) provisioning demands for food, water, energy, materials and ecosystem services.

Furthermore, the concept of CSA fails to consider possible impacts of agriculture on other ecosystem services, biodiversity conservation and broader social, political and cultural dynamics. Reducing GHG emissions or improving resilience may not always result in the best natural resource management outcomes if consequences include biodiversity loss, degradation of cultural heritage, increased social inequity or long-term ecosystem instability [7].

Finally, CSA has been defined to focus exclusively in developing countries because national food security and development goals have been implicitly and incorrectly understood as issues of importance only in the developing world [3]. This focus has engendered opposition from those who fear that some developed countries may insist on mitigation of agricultural GHG emissions as a condition of continued development aid. Food security, nutritional security and nutritional health are obviously not limited to the developing world; there is also a widespread prevalence of food insecurity in high-income countries, where there are different, but overlapping, policy, governance and technical challenges [8]. With regard to the recent focus on smallholder farmers [4], the policy dialogue about CSA now systematically overlooks any impacts and opportunities connected to innovations and implications of 
large-scale agricultural practices for and in food systems in both developing and developed country contexts, further reducing the utility of the CSA framework.

In summary, the current framing of CSA gives no specific direction, no new science agenda, no ability to negotiate and prioritize contentious and conflicting agendas and no compelling reason to increase or shift investment, despite the monumental importance of these challenges in the coming decades. In fact, current agricultural practices are neither smart nor dumb. Our current agricultural and food systems are simply the manifestations of political, biophysical, socioeconomic and other influences that lead to sustainable or unsustainable outcomes, depending on the perspectives, scales, valuations of trade-offs and time frames considered. In the aggregate, however, our current systems fall well outside any defensible concept of longterm safe operating space considered in human and/or environmental terms $[9,10]$. Without radical interventions and innovations to curb fundamentally extractive processes toward the renewal of the resources upon which agricultural productivity depends, we stand only to slip further away [11-14].

This recognition provides a strong mandate for agricultural systems that better meet human and environmental needs. Although major improvements in food security and livelihoods through agricultural development have been achieved, often this has occurred at the expense of nutritional health and environmental sustainability, thereby eroding the very foundations of our long-term capacity to care for ourselves. Under current default development pathways, food systems often arise in such a way that large populations remain food-insecure while other populations begin to suffer from the pathologies of over- or malnutrition. Although equity issues dictate clear differences in responsibilities between developed and developing countries, agricultural systems that will lead to the desired outcomes of improved food security and dietary health remain common goals for our global community.

Recent reports ${ }^{\mathrm{a}}$ have set forth specific principles and recommendations to improve the sustainability of agriculture and food systems that explicitly address various threats, including that of climate change [15]. None of these reports, however, moved beyond incremental improvements to specify in any detail a future state in which we commit ourselves to a food-secure world within planetary or local boundaries over the short or long term. Recently, the Commission on Sustainable Agriculture and Climate Change synthesized a vast array of literature on agriculture, food systems, food and nutritional security, dietary health, adaptation to climate change and mitigation of agricultural GHG emissions into a series of recommended policy actions $[10,16]$. In its report, the commission extended the concept of "safe operating space" beyond the original framing, which focused on biophysical attributes of the planet, to include socialecological systems related to human welfare, agriculture and food security $[9,10,17]$.

In our view, a safe operating space for agricultural and food systems represents a set of conditions that demonstrably better meets human needs in the short and long term within foreseeable local and planetary limits and holds ourselves accountable for outcomes across temporal and spatial scales. In our view, agriculture and food systems are climate-smart when it can be shown that they bring us closer to safe operating spaces.

Although well-intentioned and potentially costly, the current mode of incremental improvement may still fall well short of achieving safer spaces. For instance, some argue that we are already able to produce enough food to feed a worldwide human population of 9 billion, especially under scenarios of improved dietary health, reduced waste and loss and diversified, intensified production systems [18]. Although this view is valid and important, we still do not know whether, even after such major shifts, our food systems would be in long-term balance with our natural resources base. Along the way, we may cross tipping points that demarcate permanent transitions to new states that will become apparent only when it is too late to turn back.

Improvements in the management of agricultural systems that bring us significantly closer to safe operating spaces (however we learn to define these conditions) will require transformational changes in governance, management and use of our natural resources that are underpinned by enabling political, social and economic conditions. This is a major challenge in itself, considering that investments in agricultural development have often yielded unintended detrimental social and environmental consequences on various spatial and temporal scales $[19,20]$.

As a coordinated international attempt to address such issues, Rio+20 member states recently reaffirmed in the outcome document "The Future We Want" their commitments regarding "the right of everyone to have access to safe, sufficient and nutritious food" [21]. India and Mexico, for example, have moved to enshrine the right to food in law and are seeking means by which to implement such policy effectively [22,23]. Although the recognition of a human right to food security places human welfare and humanitarian values at the center of development, the short- and long-term social, economic, political and environmental effects of such commitments remain unclear. For instance, how will these efforts affect a "landdegradation neutral world" that these countries committed themselves to in the same document?

To answer such a question, we need to have processes in place that can provide relevant insights into issues such as the following. Can these more holistic approaches be integrated into research and development, informing a 
robust representation of conditions on the ground in near real time and more informative tools looking forward? Can we integrate approaches and insights derived from diverse sources to predict, mitigate and innovate regarding food security and nutritional health issues in the face of climate change? What are the specific boundaries of safe spaces? How do we deal with ambiguity and uncertainty across scales and priorities? How will we describe these boundaries and how they move dynamically as the trajectories of food systems evolve? Can we identify synergistic, transformational changes that may vault us to more stable and secure food systems across scales? What governance mechanisms are needed to ensure that the benefits and costs of well-grounded choices and their positive and negative consequences are shared as equitably as possible? How will we know whether our collective investments in the future are bringing us closer to safer spaces? Can we reach a condition which we can objectively defend as a safer space at any scale before reaching critical tipping points and thresholds in Earth and human systems? How will we know whether the changes are sufficiently bold so that, by the middle of this century, we can avoid the recognition we now face with virtual certainty that our best intentions simply have not been good enough?

\section{What should we do now in research?}

Finding adequate responses to questions such as those in the preceding paragraph, as well as many more connected to reaching long-term safer spaces as our collective target, will require transformational changes in our commitment toward the future we want across all of society, including our science agenda. It means changing how we fund and evaluate agricultural research, how we evaluate agricultural practices and how we describe relevant parameters of human conditions linked to our choices in agriculture, natural resources management and food systems.

To develop an operational characterization of the safer operating spaces, working definitions of food security, resilience and mitigation are essential. It is also essential that these concepts are defined across the stakeholder dimension in addition to the spatial and temporal dimensions, as preferences and priorities vary significantly across institutional structures. The operational viability CSA is dependent on the resolution of these barriers (definitions and synthesis across scales) and a correct representation of trade-offs that truly informs decision-makers. The science agenda for the 21st century must improve our ability to recognize and achieve long-term safer spaces across scales for agriculture and food systems. Key areas of innovation in support of such a science agenda will not be restricted to, but will include:

\section{- Discovery, testing and implementation of mechanisms across scales that allow for adaptive}

management and adaptive governance of socialecological systems essential for long-term human provisioning: Adaptive management and governance will afford the capacity, protocols and processes to learn from mistakes and successes, including both anticipated and undesired outcomes.

- Development of integrated metrics of safe space that are practical and meaningful for decisionmaking by relevant communities in near real time: Indicators, proxies and other attributes of agricultural social-ecological systems that provide relevant feedback to stakeholders are required to monitor, evaluate and appraise changes in systems over space and in time, allowing for better decision-making and providing milestones for adaptive management.

- Systematic gathering and integration of quality data and information to generate knowledge in time frames and at scales relevant for decision-making through analytical tools, models and scenarios: Describing the consequences of our provisioning demands and choices in human and ecological terms requires the integration of high-quality data into knowledge for improved decision-making that will increasingly be collected, filtered, analyzed and interpreted by using automated self-learning algorithms to transform the vast amounts of data into useful information. Drawing on technological and computation innovations already in place as well as implementing strategic funding investments would help to bridge the gap between the developing and developed scientific communities.

- Establishment of legitimate and empowered science policy dialogues that frame post-disciplinary science agendas on local, national and international scales: Dialogues and roundtables between relevant stakeholders that scientifically test decisions at the interface of diverging interests of business, environment and civil constituencies in often contentious topical areas can improve outcomes and help identify scientifically credible interpretations of long-term safe operating spaces in the context of a changing climate and growing environmental and societal changes.

Shifting our agricultural and food systems toward development trajectories that with greater certainty can be defined as safe is what we understand as being truly climate-smart. Although the areas of innovation described above will not take us to safer spaces for humanity without massive investments in sustainable natural resource management, a transformation of global food systems and ambitious low emissions development pathways, they will improve our ability to predict whether our investments in 
future agricultural and food systems can be considered climate-smart with greater certainty.

\section{Endnote}

${ }^{a}$ Also see Commission on Sustainable Agriculture and Climate Change, Achieving Food Security in the Face of Climate Change; World Bank, World Development Report; Organization for Economic Cooperation and Development (OECD), Green Growth Strategy for Food and Agriculture and Green Growth Knowledge Platform (http://www.oecd.org/greengrowth/greengrowth knowledgeplatform.htm); United Nations Environment Program (UNEP) and International Water Management Institute (IWMI), Ecosystems for Water and Food Security; Food and Agriculture Organization of the United Nations (FAO), Climate-Smart Agriculture Sourcebook and How to Feed the World in 2050; Foresight, Report on Global Food and Farming Futures; International Assessment of Agricultural Knowledge, Science and Technology for Development (IAASTD), Synthesis Report; United Nations High Level Task Force on the Global Food Security Crisis (http://www.un.org/en/issues/food/taskforce/); Millennium Ecosystem Assessment Reports (http://www.unep.org/ maweb/en/index.aspx); World Economic Forum (WEF), Realizing a New Vision for Agriculture: A Roadmap for Stakeholders.

\section{Competing interests}

The authors declare that they have no competing interests.

\section{Authors' contributions}

$\mathrm{HN}$ and $\mathrm{MJ}$ are co-first authors. $\mathrm{HN}$ and $\mathrm{MJ}$ developed the outline and drafted the manuscript. BMC, FDC, ADP, JG, JH, MH, HM, MS, SV and EW contributed to the evolving outline. $B C, J R B, F D C, A D P, J H, M H, A J, D L Z, H M$ $T R, M S, R S, S V, E W$ and RZ provided input to the writing of the manuscript. All authors read and approved the final manuscript.

\section{Acknowledgements}

We would like to acknowledge support provided by the CGIAR Research Program on Climate Change, Agriculture and Food Security (CCAFS).

\footnotetext{
Author details

${ }^{1}$ World Agroforestry Centre (ICRAF), Nairobi, Kenya. ${ }^{2}$ Department of Agronomy and Laboratory of Genetics, University of Wisconsin, Madison, WI, USA. ${ }^{3}$ CGIAR Research Program on Climate Change, Agriculture and Food Security, Cali, Colombia. ${ }^{4}$ International Center for Tropical Agriculture (CIAT), Cali, Colombia. ${ }^{5}$ Government Office of Science, London, UK. ${ }^{6}$ Bioversity International, Montpellier, France. ${ }^{7}$ International Food Policy Research Institute (IFPRI), Washington, DC, USA. ${ }^{8}$ Environmental Sciences Division, Oak Ridge National Laboratory, Oak Ridge, TN, USA. ${ }^{9}$ International Maize and Wheat Improvement Center (CIMMYT), Texcoco, Mexico. ${ }^{10}$ Commonwealth Scientific and Industrial Research Organisation (CSIRO), Brisbane, Australia.

${ }^{11}$ Tasmanian Institute of Agriculture, University of Tasmania, Hobart, Australia.

${ }^{12}$ Centre for Crop Systems Analysis, Wageningen University, Wageningen, The Netherlands. ${ }^{13}$ School of Animal, Plant and Environmental Science, University of Witwatersrand, Johannesburg, South Africa. ${ }^{14}$ Council for Scientific and Industrial Research (CSIR), Cape Town, South Africa. ${ }^{15}$ Department of Plant and Environmental Sciences, Faculty of Science, University of Copenhagen, Copenhagen, Denmark. ${ }^{16} \mathrm{Gund}$ Institute for Ecological Economics, University of Vermont, Burlington, VT, USA. ${ }^{17}$ International Crops Research Institute for the Semi-Arid Tropics (ICRISAT), Bamako, Mali.
}

Received: 7 June 2013 Accepted: 14 August 2013

Published: 30 August 2013

\section{References}

1. Food and Agriculture Organization of the United Nations: Food Security and Agricultural Mitigation in Developing Countries: Options for Capturing Synergies. Rome; 2009.

2. Food and Agriculture Organization of the United Nations: Harvesting Agriculture's Multiple Benefits: Mitigation, Adaptation, Development and Food Security. Rome; 2009.

3. Food and Agriculture Organization of the United Nations: "Climate-Smart" Agriculture: Policies, Practices and Financing for Food Security, Adaptation and Mitigation. Rome; 2010.

4. Food and Agriculture Organization of the United Nations: Climate-Smart Agriculture Sourcebook. Rome; 2013.

5. Tilman D, Balzer C, Hill J, Befort BL: Global food demand and the sustainable intensification of agriculture. Proc Natl Acad Sci USA 2011, 108:20260-20264.

6. Hershey CH, Neate P: Eco-Efficiency: From Vision to Reality. Cali, Colombia: International Center for Tropical Agriculture (CIAT); 2013.

7. McCarthy N, Lipper L, Mann W, Branca G, Capaldo J: Evaluating synergies and trade-offs among food security, development and climate change. In Climate Change Mitigation and Agriculture. Edited by Wollenberg E, Nihart A, Tapio-Biström ML, Grieg-Gran M. London: Earthscan; 2012:39-49.

8. Coleman-Jensen A, Nord M, Andrews M, Carlson S: Household Food Security in the United States in 2010. Washington, DC: Economic Research Service, US Department of Agriculture; 2011.

9. Rockström J, Steffen W, Noone K, Persson A, Chapin FS 3rd, Lambin EF, Lenton TM, Scheffer M, Folke C, Schellnhuber HJ, Nykvist B, de Wit CA, Hughes T, van der Leeuw S, Rodhe H, Sörlin S, Snyder PK, Costanza R, Svedin U, Falkenmark M, Karlberg L, Corell RW, Fabry VJ, Hansen J, Walker B, Liverman D, Richardson K, Crutzen P, Foley JA: A safe operating space for humanity. Nature 2009, 461:472-475.

10. Beddington J, Asaduzzaman M, Clark M, Fernández A, Guillou M, Jahn M, Erda L, Mamo T, Van Bo N, Nobre C, Scholes R, Sharma R, Wakhungu J: Achieving Food Security in the Face of Climate Change: Final Report from the Commission on Sustainable Agriculture and Climate Change. Copenhagen: CGIAR Research Program on Climate Change, Agriculture and Food Security (CCAFS); 2012. Available at: http://ccafs.cgiar.org/sites/default/files/assets/docs/ climate_food_commission-final-mar2012.pdf (accessed 15 August 2013).

11. United Nations Environment Program: Global Environment Outlook 5: Environment for the Future We Want. Nairobi: Author; 2012.

12. Millennium Ecosystem Assessment: Ecosystems and Human Well-Being: Synthesis. Washington, DC: Island Press; 2005

13. Stern N: The Economics of Climate Change. Cambridge, UK: Cambridge University Press; 2007.

14. Bernstein L, Bosch P, Canziani O, Chen Z, Christ R, Davidson O, Hare W, Huq S, Karoly D, Kattsov V, Kundzewicz Z, Liu J, Lohmann U, Manning M, Matsuno T, Menne B, Metz B, Mirza M, Nicholls N, Nurse L, Pachauri R, Palutikof J, Parry M, Qin D, Ravindranath N, Reisinger A, Ren J, Riahi K, Rosenzweig C, Rusticucci M, et al: Climate Change 2007: Synthesis Report. Contribution of Working Groups I, II and III to the Fourth Assessment Report of the Intergovernmental Panel on Climate Change. In Edited by Core Writing Team, Pachauri RK, Reisinger A. Geneva: Intergovernmental Panel on Climate Change; 2007. Available at: http://www.ipcc.ch/pdf/ assessment-report/ar4/syr/ar4_syr.pdf (accessed 15 August 2013).

15. McKenzie F, Ashton R: Safeguarding and Enhancing the Ecological Foundation of Agricultural and Food Systems to Support Human Well-being: Bridging the Implementation Gap. Nairobi: United Nations Environment Programme. Available at: http://www.geosci.usyd.edu.au/documents/fiona1. pdf (accessed 15 August 2013).

16. Beddington JR, Asaduzzaman M, Clark ME, Fernández Bremauntz A, Guillou MD, Howlett DJB, Jahn MM, Lin E, Mamo T, Negra C, Nobre CA, Scholes RJ, Van Bo N, Wakhungu J: Agriculture: What next for agriculture after Durban? Science 2012, 335:289-290.

17. Ostrom E: A general framework for analyzing sustainability of social-ecological systems. Science 2009, 325:419-422.

18. Foley JA, Ramankutty N, Brauman KA, Cassidy ES, Gerber JS, Johnston M, Mueller ND, O'Connell C, Ray DK, West PC, Balzer C, Bennett EM, Carpenter SR, Hill J, Monfreda C, Polasky S, Rockström J, Sheehan J, Siebert S, Tilman D, Zaks DPM: Solutions for a cultivated planet. Nature 2011, 478:337-342. 
19. Leith P, Meinke H: Overcoming adolescence: Tasmania's agricultural history and future. Griffith Rev 2013:39. Available at: http://griffithreview. com/edition-39-tasmania-the-tipping-point/overcoming-adolescence (accessed 15 August 2013).

20. Tàbara JD, Chabay I: Coupling human information and knowledge systems with social-ecological systems change: reframing research, education, and policy for sustainability. Environ Sci Policy 2012, 28:71-81.21.

21. United Nations General Assembly: The Future We Want, Rio+20 Outcome Document. Resolution adopted by the General Assembly at the 123rd plenary meeting 27 July 2012. A/RES/66/288. Available at: http://unstats.un. org/unsd/broaderprogress/pdf/GA\%20Resolution\%20-\%20The\%20future\% 20we\%20want.pdf (accessed 15 August 2013).

22. Kasmin A: Delhi pushes through right-to-food programme as hunger persists. Financial Times 3 July 2013.

23. Office of the High Commissioner for Human Rights, United Nations Human Rights: Mexico: UN Expert welcomes constitutional recognition of the right to food. Available at: http://www.ohchr.org/en/NewsEvents/Pages/

DisplayNews.aspx?NewsID=11491\&LangID=E (accessed 15 August 2013).

doi:10.1186/2048-7010-2-12

Cite this article as: Neufeldt et al.: Beyond climate-smart agriculture:

toward safe operating spaces for global food systems. Agriculture \& Food Security 2013 2:12.

\section{Submit your next manuscript to BioMed Central and take full advantage of:}

- Convenient online submission

- Thorough peer review

- No space constraints or color figure charges

- Immediate publication on acceptance

- Inclusion in PubMed, CAS, Scopus and Google Scholar

- Research which is freely available for redistribution 